\title{
Karakteristik dan Tipologi Industri Mikro, Kecil, dan Menengah Agroindustri Apel di Kota Batu
}

\section{Ringga Pridiatama, Andri Kurniawan dan Sudrajat}

Masuk: 1105 2019 / Diterima: 30052019 / Dipublikasi: 30062019

(c) 2019 Fakultas Hukum dan IImu Sosial UNDIKSHA dan IGI

\begin{abstract}
Indonesia is known as an agricultural country. Agro-industry activities have an important role in supporting the agricultural sector both economically and socially. Apple is a typical fruit from Batu City and has been processed into various kinds of products, both food and beverages. Unfortunately, there is currently a decrease in Apple productivity. This is mainly caused by non-climate factors like land conversion, cultivation constraints, and declines in apple prices. The objectives of this study were to know the characteristics and typology of apple agroindustry in Batu City. This study uses descriptive quantitative methods. The sampling technique in this study was census sampling on 47 micro, small and medium scale agro-industry players in Batu City. The analysis data were obtained from structured interviews using questionnaires. The results of the study showed that the apple Agroindustry in Batu City was dominated by the micro and small scale industry, the low education level of the industry players, and the marketing distribution that only limited to regional and national. In the industrial typology, $17.02 \%$ was classified as advanced, $34.04 \%$ was classified as developing, and $48.93 \%$ was classified as underdeveloped.
\end{abstract}

Key words: Agro-industry; characteristics; typology

\begin{abstract}
Abstrak Indonesia dikenal sebagai negara agraris. Kegiatan agroindustri memiliki peran penting untuk mendukung sektor pertanian baik dari segi ekonomi maupun sosial. Apel menjadi buah yang khas dari oleh Kota Batu dan telah banyak diolah menjadi berbagai macam produk baik makanan maupun minuman. Produktivitas apel mengalami penurunan yang mayoritas disebabkan faktor noniklim diantaranya konversi lahan, kendala budidaya, serta harga apel yang menurun. Tujuan penelitian ini adalah mengetahui karakteristik dan tipologi agroindustri apel di Kota Batu. Penelitian ini menggunakan metode deskriptif kuantitatif. Pengambilan sampel dilakukan secara sensus pada 47 pelaku agroindustri apel skala industri mikro, kecil, dan menengah di Kota Batu. Pengambilan data dilakukan melalui wawancara terstruktur menggunakan kuesioner. Hasil penelitian menunjukkan bahwa agroindustri apel di Kota Batu didominasi skala mikro dan kecil, tingkat pendidikan rendah, serta lingkup pemasaran terbatas pada lingkup lokal dan nasional. Pada tipologi klaster industri menunjukkan sebanyak $17,02 \%$ tergolong maju, 34,04\% tergolong berkembang, dan 48,93\% tergolong terbelakang.
\end{abstract}

Kata kunci: agroindustri; karakteristik; tipologi

\section{Pendahuluan}

Sektor pertanian memegang peran penting dalam menopang perekonomian Indonesia. Oleh sebab itu pemerintah memberikan perhatian yang besar terhadap sektor pertanian, salah satunya tertuang dalam Rencana Induk Pembangunan Nasional (RIPIN) 20152035 yang memuat strategi

Ringga Pridiatama, Andri Kurniawan dan Sudrajat Universitas Gadjah Mada, Yogyakarta ringga.pridiatama@gmail.com pengembangan industri hulu dan industri antara berbasis sumberdaya alam. Target utamanya adalah meningkatkan nilai tambah sumberdaya alam pada industri hulu berbasis agro guna memantapkan kesiapan pada aspek hulu (pertanian) dalam mewujudkan industrialisasi yang tangguh.

Dalam

perkembangannya, kegiatan pertanian seringkali menimbulkan ketidakpastian dari segi ekonomi. Gambaran mengenai kondisi kesejahteraan petani di Jawa Timur 
menurut BPS (2014) menyebutkan bahwa sebesar $40,07 \%$ dialami oleh penduduk yang bekerja di sektor pertanian. Kondisi tersebut sangat berbanding terbalik dengan jasa para petani dalam mengupayakan ketahanan dan kedaulatan pangan. Kondisi sektor pertanian yang demikian dapat diminimalisir dengan adanya kegiatan agroindustri. Hal tersebut sejalan dengan penelitian yang dilakukan oleh Pratiwi dkk (2017) yang menemukan bahwa agroindustri hilir memiliki pengaruh yang besar dalam usaha pemerataan pendapatan melalui kegiatan pengolahan dan pengawetan makanan.

Kota Batu sebagai wilayah dengan basis utama pada sektor pertanian memiliki berbagai potensi, salah satunya melalui buah apel sebagai unggulannya. Meskipun berbagai produk pertanian seperti sayuran, tanaman hias, dan buahbuahan lainnya banyak dibudidayakan, buah apel telah melekat menjadi ciri khas tersendiri bagi Kota Batu. Produktivitas apel di Kota Batu mengalami penurunan, hal tersebut disebabkan oleh berbagai faktor. Menurut Ruminta (2015) penurunan produktivitas apel dipengaruhi oleh faktor non-iklim, diantaranya ialah permasalahan pada budidaya, tanaman apel berumur tua, adanya konversi lahan tanaman apel, serta harga komoditas apel yang menurun.

Kondisi fluktuasi produktivitas apel di Kota Batu mendapatkan perhatian yang serius dari pemerintah setempat. Upaya mengatasi permasalahan produktivitas apel tersebut dirumuskan dalam program pengembangan agribisnis apel melalui tiga program prioritas yakni 1). Penghambatan laju degradasi dan perbaikan mutu lahan, 2). Pengawalan teknologi dan penelitian budidaya apel ramah lingkungan, 3) pembentukan dan penguatan kelembagaan agribisnis apel (Suhariyono, 2014). Selain itu, upaya lain juga dituliskan pemerintah Kota Batu dalam RPJMD Kota Batu yang mempunyai visi pembangunan yang bertumpu pada sektor pertanian, IKM, dan pariwisata.

Berkenaan dengan pentingnya peran agroindustri dalam kaitannya menambah nilai guna maupun ekonomis, maka penting untuk dilakukan kajian terhadap kondisi agroindustri apel di kota Batu. Tujuan penelitian ini adalah mengetahui karakteristik dan tipologi agroindustri apel di Kota Batu.

\section{Metode}

Lokasi penelitian dilakukan di Kota Batu Jawa Timur. Pemilihan lokasi dilakukan dengan pertimbangan bahwa sentra utama produksi apel di Indonesia berada di Jawa Timur, salah satunya Kota Batu. Selain itu visi dan misi pada dokumen RPJMD Kota Batu juga bertumpu pada tiga sektor utama, yakni pertanian, pariwisata, dan IKM. Data yang digunakan merupakan data primer dan sekunder yang diperoleh melalui observasi lapangan, wawancara terstruktur menggunakan kuesioner, serta data sekunder dari Pemerintah Kota Batu terkait agroindustri apel. Metode yang digunakan adalah deskriptif kuantitatif. Populasi pada penelitian ini adalah semua agroindustri apel berskala mikro, kecil, dan menengah di Kota Batu. Penelitian ini menggunakan metode sensus untuk menentukan sampel sebanyak 47 agroindustri apel. Analisis karakteristik agroindustri dilakukan secara deskriptif kuantitatif menggunakan crosstab dan uji chi kuadrat menggunakan software spss. Sedangkan untuk menentukan tipologi agroindustri apel digunakan teknik skoring dan pembobotan dengan skala data nominal. Adapun hipotesis penelitian ini meliputi: a). Terdapat perbedaan yang signifikan antara tingkat pendidikan pengusaha dengan skala industri, b). Terdapat perbedaan yang signifikan antara asal bahan baku dengan skala industri, c). Terdapat perbedaan yang 
signifikan antara lingkup pemasaran dengan skala industri.

\section{Hasil dan Pembahasan}

\subsection{Karakteristik agroindustri apel di Kota Batu}

1) Karakteristik industri

Karakteristik agroindustri apel dibedakan menjadi tiga, yakni pada skala mikro, kecil, dan menengah sesuai klasifikasi Departemen Perindustrian (2010) yang mengacu pada jumlah tenaga kerja yang terlibat didalamnya. Klasifikasi tersebut membedakan skala industri mikro memiliki jumlah pekerja 1 hingga 4 orang, skala industri kecil 5 hingga 19 orang, serta skala industri menengah 20 hingga 30 orang. Pada Tabel 1 menunjukkan bahwa pada Kecamatan batu total jumlah industri sebanyak 15 buah dengan rincian terdapat 8 tergolong skala mikro, 7 skala kecil dan menengah. Pada Kecamatan Bumiaji total industri sebanyak 29 buah dengan rincian 13 termasuk skala mikro dan 16 buah pada skala kecil dan menengah. Kemudian pada Kecamatan Junrejo total industri yakni 3 dengan jenis skala kecil.

Tabel 1. Karakteristik Skala Industri

\begin{tabular}{lccccc}
\hline & \multicolumn{4}{c}{ Skala Industri } & \\
\cline { 2 - 5 } & Kec. & Mikro & $\%$ & $\begin{array}{c}\text { Kecil\& } \\
\text { Menengah }\end{array}$ & Jml \\
\hline Batu & 8 & 53 & 7 & 46 & 15 \\
\hline Bumiaji & 13 & 45 & 16 & 55 & 29 \\
\hline Junrejo & 0 & 0 & 3 & 100 & 3 \\
\hline Jumlah & 21 & \multicolumn{5}{c}{26} & 47 \\
\hline \multicolumn{5}{l}{ Sumber: Data primer, 2019}
\end{tabular}

Karakteristik

agroindustri

berdasarkan jumlah pekerja juga diungkapkan oleh Hanafie, dkk (2016) dengan temuan bahwa jumlah pekerja pada industri pengolahan makanan berbasis singkong di Trenggalek, Tulungagung, dan Kabupaten Malang berkisar antara satu hingga tiga orang (skala mikro), penggunaan teknologi yang masih sederhana, serta pemasaran produk pada daerah setempat. Temuan mengenai karakteristik skala agroindustri dapat memberikan kontribusi dalam pendekatan pembuatan keputusan. Soekartawi (2000) menyebutkan bahwa pembinaan perusahaan agroindustri oleh pemerintah dapat dilakukan sesuai skala usaha untuk memberikan proporsi yang efektif, dimana semakin besar skala usaha, maka peran pemerintah semakin kecil dan begitu pula sebaliknya.
2) Karakteristik pendidikan pengusaha Karakteristik pengusaha disajikan pada Tabel 2. Karakteristik pengusaha dilihat dari tingkat pendidikan terakhir yang ditempuh, pada penelitian ini pendidikan dibedakan menjadi dua yaitu rendah dan tinggi. Pada tingkat pendidikan rendah pendidikan terakhir yang ditempuh yakni SMP dan SMA, sedangkan pada tingkat pendidikan tinggi merupakan lulusan sarjana atau S1. Pada skala industri mikro, terdapat 16 industri yang pengusahanya berlatar pendidikan rendah dan terdapat 5 pengusaha berpendidikan tinggi. Sedangkan pada skala industri kecil dan menengah terdapat 18 pengusaha berpendidikan rendah dan 8 pengusaha berpendidikan tinggi. 
Tabel 2. Karakteristik Pengusaha

\begin{tabular}{ccccc}
\hline \multirow{2}{*}{ Skala Industri } & \multicolumn{4}{c}{ Tingkat Pendidikan } \\
\cline { 2 - 5 } & Rendah & $\%$ & Tinggi & $\%$ \\
\hline Mikro & 16 & 34 & 5 & 11 \\
\hline Kecil \& Menengah & 18 & 38 & 8 & 17 \\
\hline Total & 34 & 45 & 13 & 28 \\
\hline
\end{tabular}

Sumber: Data primer, 2019

Gambaran mengenai karakteristik agroindustri di Kota Batu tersebut sesuai dengan ciri khas yang diutarakan oleh Tambunan (2000) bahwa karakteristik industri mikro, kecil, dan menengah merupakan berbasis agrikultur, dimiliki masyarakat lokal, serta mayoritas memiliki pendidikan rendah. Agroindustri di Kota Batu mayoritas dimiliki oleh pengusaha lulusan SMP dan SMA, sehingga dikategorikan berpendidikan rendah. Sedangkan 13 agroindustri dimiliki oleh pengusaha berpendidikan tinggi.

Berdasarkan hasil uji chi square, diperoleh nilai Asymp. Sig sebesar 0.596 atau lebih besar daripada nilai signifikansinya 5\%. Dari nilai tersebut dapat disimpulkan bahwa HO diterima, yang artinya tidak ada perbedaan yang signifikan antara tingkat pendidikan dengan karakteristik skala industri apel di Kota Batu Jawa Timur.

3) Karakteristik bahan baku

Buah apel dan jeruk merupakan jenis buah terbesar yang dihasilkan Kota Batu (BPS, 2018). Dari berbagai jenis apel, terdapat tiga jenis yang digunakan oleh pengusaha, yakni manalagi, romebeauty, dan anna. Karakteristik bahan baku dibedakan dari asal mula apel diperoleh, apakah dari Kota Batu atau kombinasi antara Kota Batu dengan wilayah lain di luar Kota Batu. Berdasarkan Tabel 3 diketahui bahwa bahan baku apel yang berasal dari Kota Batu digunakan oleh 14 industri mikro dan 7 industri kecil dan menengah. Sedangkan bahan baku yang berasal dari kombinasi Kota Batu dengan wilayah lain digunakan sebanyak 7 industri berskala mikro dan 19 industri dengan skala kecil dan menengah. Bahan baku apel yang digunakan secara dominan berasal dari kombinasi Kota Batu dan wilayah lain mendominasi secara keseluruhan industri yakni sebanyak 26 industri dari total 47 industri. Menurut penuturan pelaku industri, apel dari wilayah lain tersebut didapatkan dari daerah Pasuruan (Nongkojajar) dan Kabupaten Malang (Pujon dan Poncokusumo).

Tabel 3. Karakteristik Bahan Baku

\begin{tabular}{lcccc}
\hline \multirow{2}{*}{ Skala Industri } & \multicolumn{4}{c}{ Asal Bahan Baku } \\
\cline { 2 - 5 } Mikro & Kota Batu & $\%$ & Kombinasi & $\%$ \\
\hline Kecil \& Menengah & 14 & 30 & 7 & 15 \\
\hline Total & 7 & 15 & 19 & 40 \\
\hline \multicolumn{4}{c}{ Sumber: Data primer, 2019}
\end{tabular}

Berdasarkan asal bahan baku yang dipergunakan dalam proses produksi, pada skala mikro menunjukkan bahwa buah apel dari Kota Batu dominan digunakan. Hal tersebut juga diungkapkan oleh Soekartawi (2007) bahwa salah satu karakteristik agroindustri identik dengan penggunaan bahan baku lokal. Pada 
kenyataanya, di Kota Batu produktivitas apel menurun manurut beberapa pengusaha. Hal tersebut dapat dilihat dari perubahan penggunaan lahan di Kota Batu sendiri. Turunnya produktivitas apel dipengaruhi oleh kondisi iklim, penyakit, maupun biaya perawatan yang tinggi sehingga buah apel juga didatangkan daerah lain seperti Kabupaten Malang dan Pasuruan. Oleh karena itu, pada industri dengan skala kecil dan menengah asal bahan baku lebih didominasi apel yang berasal dari Kota Batu dan daerah lain untuk mencukupi kebutuhan produksi. Kondisi yang demikian memerlukan tindakan lebih lanjut agar keberlanjutan agroindustri apel di Kota Batu dapat berkelanjutan. Hasil penelitian Suryaningrat (2016) menyimpulkan bahwa keberlanjutan ketersediaan bahan mentah memegang peran penting bagi produktivitas industri pengolahan buah.

Berdasarkan hasil uji chi square, diperoleh nilai Asymp. Sig sebesar 0.006. Dari nilai tersebut dapat disimpulkan bahwa $\mathrm{HO}$ ditolak, yang artinya ada perbedaan yang signifikan antara asal bahan baku dengan karakteristik skala industri apel di Kota Batu Jawa Timur.

4) Karakteristik lingkup pemasaran

Karakteristik lingkup pemasaran dibagi menjadi dua, yakni skala lokal (meliputi Kota Batu) dan nasional. Pada Tabel 4 diketahui bahwa terdapat 6 industri mikro dengan lingkup pemasaran lokal dan 15 industri mencapai lingkup nasional. Pada lingkup nasional, pemasaran hasil olahan apel telah menjangkau Pulau Jawa, Sumatra, dan beberapa wilayah Kalimantan. Pada industri kecil dan menengah terdapat 6 industri dengan lingkup pemasaran lokal dan 20 industri mencapai lingkup nasional. Dari keseluruhan industri belum ada yang memiliki pasar internasional. Dalam wawancara dengan pelaku juga diketahui bahwa produk mereka belum cocok dengan selera luar negeri, salah satu alasannya ialah kemasan yang belum memadai. Namun beberapa pelaku industri pernah ikut dalam pameran yang diadakan dinas perindustrian. Kondisi tersebut menunjukkan kurangnya inovasi pada agroindustri apel di Kota Batu, sehingga hal tersebut kurang memberikan keuntungan dalam persaingan. Distanont dan Khongmalai (2018) memperoleh temuan bahwa faktor inovasi dapat meningkatkan persaingan, inovasi sebagai alat strategis untuk peningkatan keunggulan kompetitif.

Tabel 4. Karakteristik Lingkup Pemasaran

\begin{tabular}{ccccc}
\hline \multirow{2}{*}{ Skala Industri } & \multicolumn{4}{c}{ Lingkup Pemasaran } \\
\cline { 2 - 5 } & Lokal & $\%$ & Nasional & $\%$ \\
\hline Mikro & 6 & 13 & 15 & 32 \\
\hline Kecil \& Menengah & 6 & 13 & 20 & 42 \\
\hline Total & 12 & 26 & 35 & 74 \\
\hline
\end{tabular}

Sumber: Data primer, 2019

Berdasarkan hasil uji chi square, diperoleh nilai Asymp. Sig sebesar 0.668. Dari nilai tersebut dapat disimpulkan bahwa $\mathrm{HO}$ diterima, yang artinya tidak ada perbedaan yang signifikan antara lingkup pemasaran dengan karakteristik skala industri apel di Kota Batu Jawa Timur.
Karakteristik agroindustri apel di Kota Batu telah dijabarkan pada beberapa sub bab sebelumnya. Secara garis besar dapat disimpulkan bahwa menurut skala industri, mayoritas berada pada skala mikro walaupun secara matematis jumlah industri kecil dan menengah lebih banyak 
karena merupakan gabungan keduanya. Pada karakteristik pendidikan pengusaha menunjukkan bahwa mayoritas berada pada kategori rendah. Karakteristik bahan baku menunjukkan hasil bahwa pada skala industri mikro penggunaan bahan baku cenderung dari apel lokal yakni dari Kota Batu sendiri, sedangkan pada skala kecil dan menengah apel yang digunakan merupakan berasal dari kombinasi Kota Batu dan wilayah lain. Kondisi tersebut perlu menjadi perhatian berbagai pihak untuk memastikan ketersediaan sekaligus keberlanjutan produktifitas apel dari Kota Batu agar identitasnya memiliki keberlanjutan. Kemudian dari karakteristik lingkup pemasaran sudah menjangkau wilayah Indonesia secara nasional, sehingga kedepannya diharapkan produkproduk industri lokal dapat meningkatkan pemasaran hingga level internasional sesuai dengan perkembangan dan tuntutan zaman.

\subsection{Tipologi Agroindustri Apel di Kota Batu}

Penentuan mengenai tipologi penting dilakukan, karena dapat menunjukkan kondisi obyek penelitian sesuai klasifikasi yang ditentukan. Seperti pada Peraturan Menteri Perindustrian Republik Indonesia nomor 118/MIND/PER/10/2009 tentang peta panduan (road map) pengembangan klaster industri pengolahan buah yang memiliki sasaran tersedianya data dan informasi potensi bahan baku, peningkatan diversifikasi, serta adanya peningkatan kerjasama. Sasaran jangka panjang program tersebut adalah pengembangan integrasi industri baik dengan bahan baku, pasar domestik dan internasional, hingga diversifikasi produk lebih lanjut. Penelitian Purba, dkk (2018) menghasilkan temuan bahwa penentuan tipologi berbasis inovasi memberikan gambaran perbedaan karakteristik pada industri manufaktur maupun jasa, sedangkan pada industri makanan inovasi memiliki prospek kedepan bila dilakukan inovasi pada tenaga kerja yang sedikit dengan tingkat ketrampilan dan pendidikan tinggi. Hal tersebut berhubungan denga strategi pemasaran.

Sebagai upaya dalam strategi membangun agribisnis yang berdaya saing, Irawan dan Ariningsih (2014) menyebutkan perlu adanya keterkaitan kegiatan dalam sub sistem hulu, produksi, serta hilir. Selain itu, upaya pengembangan juga diarahkan berbasis kawasan, adanya pola produksi, serta penguatan infrastruktur. Melalui jabaran upaya tersebut, maka perlu dilakukan tinjauan terhadap kondisi agroindustri sebagai bagian dari agribisnis untuk mengetahui kondisi secara keseluruhan baik dari input, pengelolaan, hingga output yang didalamnya memuat unsur-unsur penting dalam meningkatkan daya saing.

Tipologi pada penelitian ini memberikan gambaran mengenai kesamaan agroindustri di Kota Batu. Kesamaan tersebut dibatasi atas tiga hal utama, yakni faktor input, pengelolaan, dan output. Ketiga faktor ini penting ditinjau untuk mengetahui rangkaian aktivitas dalam agroindustri apel dari awal hingga akhir. Faktor input memiliki indikator lokasi, bahan baku, teknologi, dan transportasi. Keempat indikator tersebut memiliki keterkaitan dalam membentuk tipologi agroindustri melalui adanya akses yang didapatkan industri untuk menjalankan usahanya. Akses dapat dijangkau melalui adanya timbal balik antara infrastruktur, alat, serta adanya hubungan antara pemberi informasi dengan pengguna (Harrington dan Warf,1995). Faktor input ini sejalan dengan hasil penelitian Tan (2000) bahwa fungsi biaya transportasi yang berkaitan dengan bahan baku memiliki peran penting dalam menentukan respon lokasional permintaan pasar. Faktor pengelolaan terdiri atas organisasi, 
kemitraan, promosi, dan jangkauan pemasaran. Sedangkan faktor output meliputi diversifikasi produk, pengemasan, limbah, serta standar produk. Tabel 5 menjelaskan faktor, indikator, serta bobot yang digunakan dalam menentukan tipologi agroindustri apel di Kota Batu. Peneliti menggunakan kuesioner untuk mengetahui kondisi input, pengelolaan, serta output pada masing-masing industri, hasil kuesioner tersebut berupa data nominal yang kemudian diberikan skor, dikalikan bobot, kemudian dijumlahkan untuk mengetahui total skor keseluruhan. Pemberian skor didasarkan pada ketersediaan faktor pada masing-masing jabaran faktor, jika memenuhi maka skor diberi 2 poin dan jika tidak terpenuhi diberi 1 poin. Hasil skor akhir kemudian diklasifikasikan menjadi tiga kategori industri, yakni maju, berkembang, dan terbelakang.

Tipologi industri apel dikategorikan menurut klaster batas administrasi yakni kecamatan. Kota Batu sendiri memiliki tiga kecamatan yakni Kecamatan Batu, Bumiaji, dan Junrejo. Melalui tipologi klaster industri, dapat menunjukkan kondisi agroindustri terkait input, pengelolaan, dan output sehingga memberikan informasi yang terpadu. Manfaat lain dari klaster industri menurut Udayana (2015) adalah sebagai upaya pengembangan kebutuhan dan manajemen terpadu untuk membangun jaringan informasi agar dapat bersaing. Selain itu penelitian mengenai tipologi klaster industri oleh Prasetyo dan Santoso (2014) menghasilkan faktor-faktor yang berpengaruh terhadap arahan pengembangan industri pengolahan jagung di Kabupaten Tuban. Sehingga dapat disimpulkan dengan adanya tipologi, akan memaparkan kondisi hingga merencanakan strategi untuk keberlanjutannya. Muta'ali (2015) menjelaskan bahwa klaster industri adalah kelompok aktivitas produksi yang terkonsentrasi secara spasial. Untuk mengetahui konsentrasi agroindustri apel di Kota Batu, akan dijabarkan tipologi agroindustri yang tersebar di masingmasing klaster kecamatan di Kota Batu yang ditunjukkan oleh gambar 1,2, dan 3 .

Tabel 5. Jabaran faktor-faktor tipologi agroindustri apel di Kota Batu

\begin{tabular}{|c|c|c|c|c|c|c|c|c|c|c|c|c|c|c|}
\hline & \multicolumn{4}{|c|}{ Faktor Input } & \multicolumn{4}{|c|}{ Faktor Pengelolaan } & \multicolumn{4}{|c|}{ Faktor Output } & \multirow{3}{*}{ Total } & \multirow{3}{*}{ Kategor } \\
\hline & A & $\mathrm{B}$ & $\mathrm{C}$ & $\mathrm{D}$ & $E$ & $\mathrm{~F}$ & $\mathrm{G}$ & $\mathrm{H}$ & $\mathrm{I}$ & $\mathrm{J}$ & $\mathrm{K}$ & $\mathrm{L}$ & & \\
\hline Bobot & 0.25 & 1 & 0.8 & 0.5 & 0.25 & 0.5 & 1 & 0.75 & 0.5 & 0.75 & 0.25 & 1 & & \\
\hline $\begin{array}{c}\text { Industri } \\
X\end{array}$ & & & & & & & & & & & & & & \\
\hline
\end{tabular}

Keterangan: A:Iokasi;B:bahan baku;C:teknologi;D:transportasi;E:organisasi;F:kemitraan;G:promosi;H: jangkauan pemasaran;I:diversifikasi produk;J:pengemasan;K:limbah;L:standar produk.

1) Tipologi industri di Kecamatan Batu

Pada Kecamatan Batu terdapat 15 agroindustri apel. Dari jumlah tersebut 4 diantaranya termasuk kategori maju, 4 berkembang, dan 7 terbelakang. Secara ringkas tipologi industri di Kecamatan Batu disajikan pada Tabel 6. Persentase tipologi dengan kategori terbelakang merupakan yang paling dominan sebesar $46,66 \%$, sedangkan kategori maju dan berkembang memiliki persentase sebesar $26,66 \%$.

Kecamatan Batu ditetapkan sebagai Bagian Wilayah Kota (BWK) I dalam dokumen RTRW. Hal tersebut menjadikan Kecamatan Batu sebagai wilayah utama pengembanagn pusat pemerintahan kota, pengembangan perdagangan dan jasa, pariwisata, jasa penunjang akomodasi wisata, serta kawasan pendidikan menengah. Oleh 
karena itu, banyak lokasi aktivitas pariwisata sebagai icon Kota Batu seperti Jatim Park 1, 2, dan 3 serta lokasi lainnya yang banyak tersebar di kecamatan ini.

Persebaran mengenai tipologi agroindustri di Kecamatan Batu disajikan pada Gambar 1. Agroindustri dengan kategori maju ditandai dengan warna biru muda. Agroindustri dengan kategori berkembang ditandai dengan warna coklat muda. Sedangkan pada agroindustri dengan kategori terbelakang ditandai dengan warna coklat tua. Secara umum persebaran agroindustri di Kecamatan Batu berlokasi pada bagian tengah wilayah administrasi Kecamatan Batu.

Tabel 6. Tipologi Industri di Kec. Batu

\begin{tabular}{lcc}
\hline \multicolumn{1}{c}{ Kategori } & Frekuensi & $\%$ \\
\hline Maju & 4 & 26,66 \\
\hline Berkembang & 4 & 26,66 \\
\hline Terbelakang & 7 & 46,66 \\
\hline Jumlah & 15 & 100 \\
\hline
\end{tabular}

Sumber: Data primer, 2019

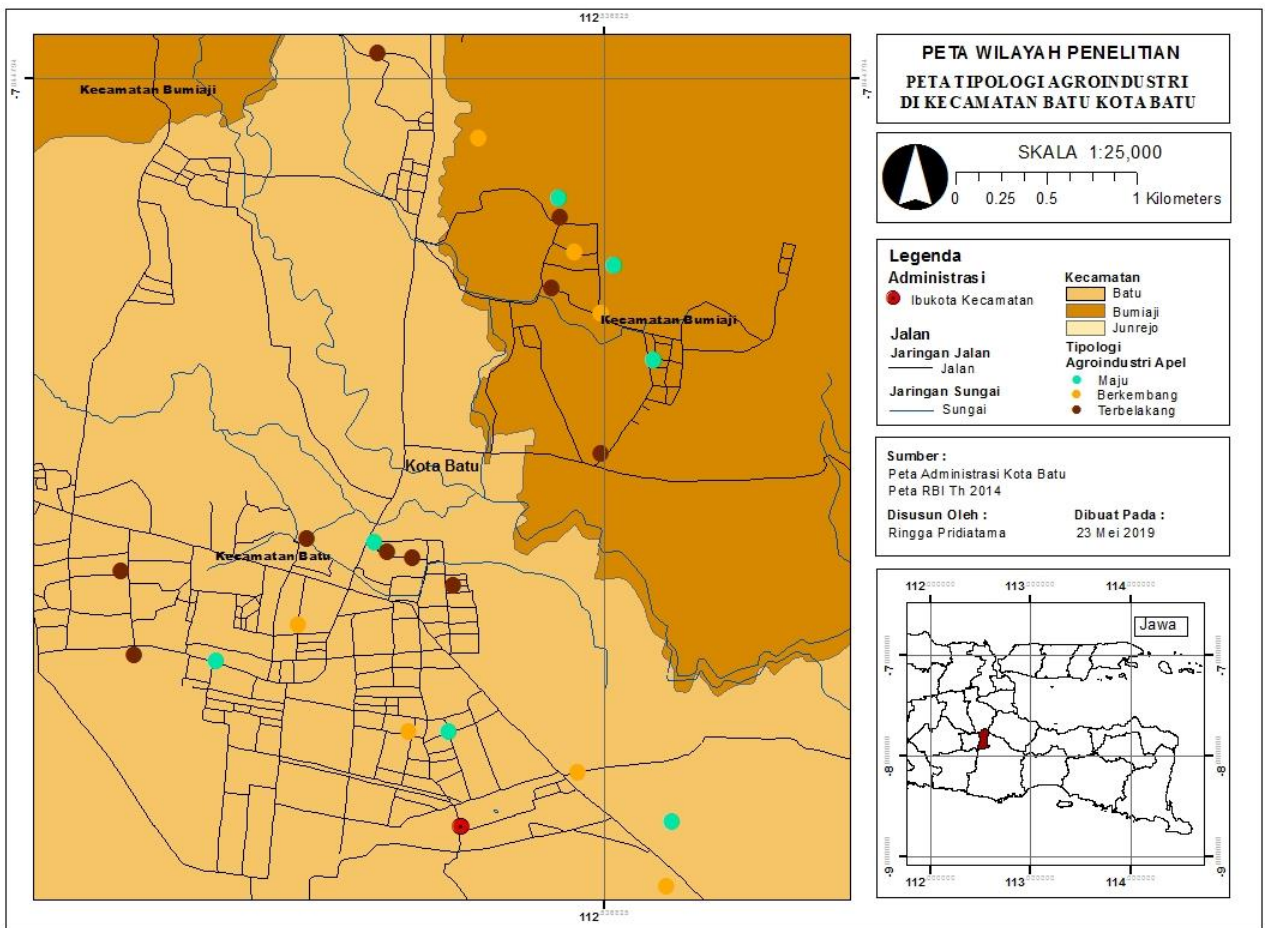

Gambar 1. Peta Tipologi Agroindustri Apel di Kecamatan Batu

2) Tipologi industri di Kecamatan Bumiaji

Tipologi industri di Kecamatan Bumiaji dapat dilihat pada Tabel 7 . Kecamatan Bumiaji memiliki industri terbanyak dengan total 29 industri. Dari keseluruhan industri, terdapat 4 industri dengan kategori maju, 11 berkembang, dan 14 terbelakang. Persentase agroindustri terbesar berada pada kategori terbelakang yakni 48,27\%, kemudian kategori berkembang sebesar $37,93 \%$, dan paling sedikit yakni kategori maju sebesar $13,79 \%$.

Gambar 2 menyajikan peta persebaran agroindustri di Kecamatan Bumiaji. Sebagai wilayah yang paling luas, kecamatan ini juga memiliki agroindustri terbanyak dari total keseluruhan 
agroindustri di Kota Batu. Lokasi agroindustri cenderung mengikuti jalan utama dan berkelompok pada desa tertentu. Kecamatan Bumiaji sangat diuntungkan dengan lokasi agroindustri yang berdekatan dengan lokasi bahan baku apel.

Fungsi wilayah Kecamatan Bumiaji ditetapkan sebagai BWK III, yang artinya sebagai wilayah utama pengembangan kawasan agropolitan, wisata alam dan lingkungan, serta agrowisata. Kondisi yang ditemukan di lapangan menujukkan kesamaan dengan dokumen RTRW Kota
Batu mengenai industri yang menyebutkan bahwa kegiatan agroindustri diarahkan di Kecamatan Bumiaji. Kemudian untuk mendukung adanya kegiatan agroindustri maka ditetapkan bahwa kawasan pertanian tanaman buahbuahan apel meliputi desa-desa yang berada di Kecamatan Bumiaji, antara lain Desa Sumbergondo, Bumiaji, Gunungsari, Giripurno, Bulukerto, dan Tulungrejo. Selain itu, Desa Bumiaji juga diarahkan sebagai kawasan strategis agrowisata perkebunan apel.

Tabel 7. Tipologi Industri di Kec. Bumiaji

\begin{tabular}{lcc}
\hline \multicolumn{1}{c}{ Kategori } & Frekuensi & $\%$ \\
\hline Maju & 4 & 13,79 \\
\hline Berkembang & 11 & 37,93 \\
\hline Terbelakang & 14 & 48,27 \\
\hline Jumlah & 29 & 100 \\
\hline \multicolumn{2}{c}{ Sumber: hasil analisis 2019}
\end{tabular}

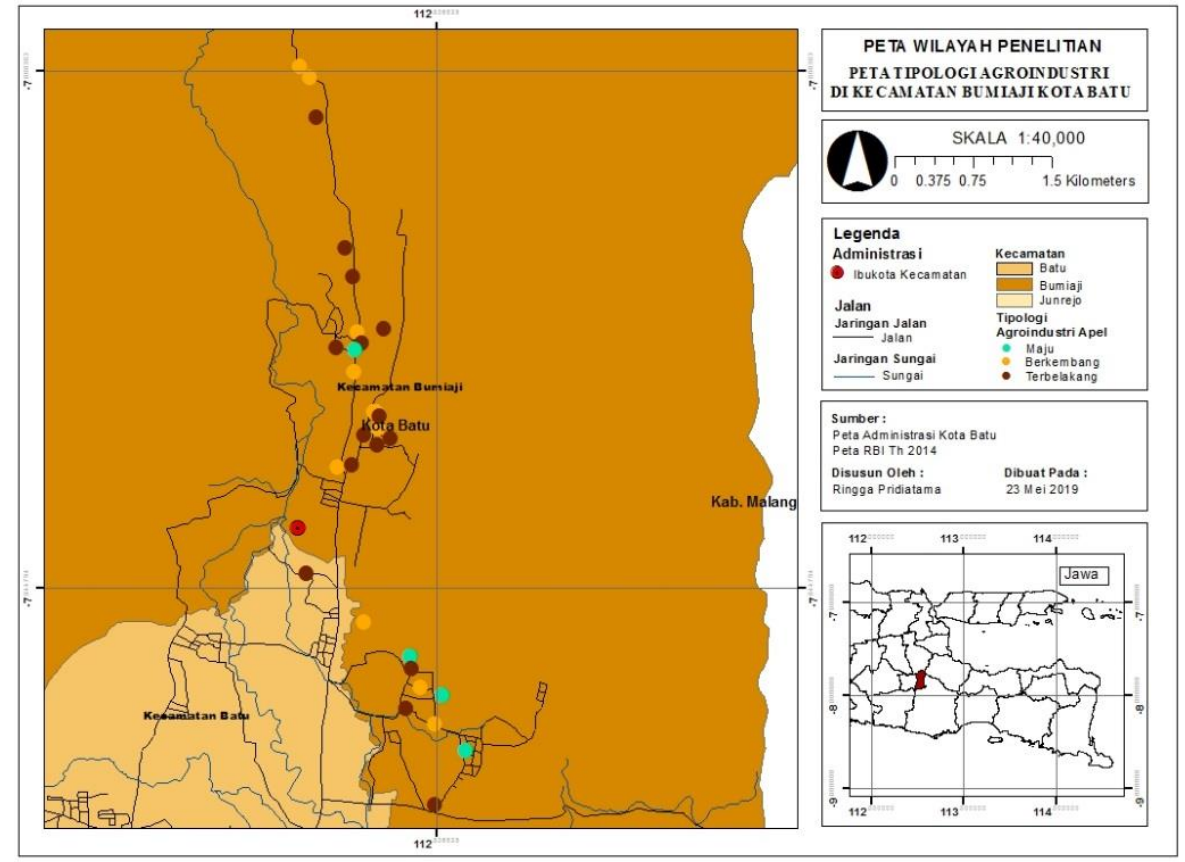

Gambar 2. Peta Tipologi Agroindustri Apel di Kecamatan Bumiaji

3) Tipologi industri di Kecamatan Junrejo

Kecamatan Junrejo memiliki jumlah agroindustri paling sedikit, yakni tiga industri. Pada kecamatan ini tidak ada industri dengan kategori maju, hanya terdapat satu kategori berkembang dan dua lainnya termasuk kategori terbelakang. Secara ringkas tipologi pada Kecamatan Junrejo disajikan pada Tabel 8. 
Gambar 3 merupakan peta tipologi di Kecamatan Junrejo. Kecamatan Junrejo merupakan BWK II sebagai wilayah utama pengembangan permukiman kota serta pusat pelayanan kesehatan, pendidikan, dan pendukung perkantoran pemerintahan maupun swasta. Selain itu, kecamatan ini juga merupakan kawasan tanaman pangan komoditas palawija.

Tabel 8. Tipologi Industri di Kec. Batu

\begin{tabular}{ccc}
\hline Kategori & Frekuensi & $\%$ \\
\hline Maju & 0 & 0 \\
\hline Berkembang & 1 & 33,33 \\
\hline Terbelakang & 2 & 66,66 \\
\hline Total & 3 & 100 \\
\hline
\end{tabular}

Sumber: Data primer, 2019

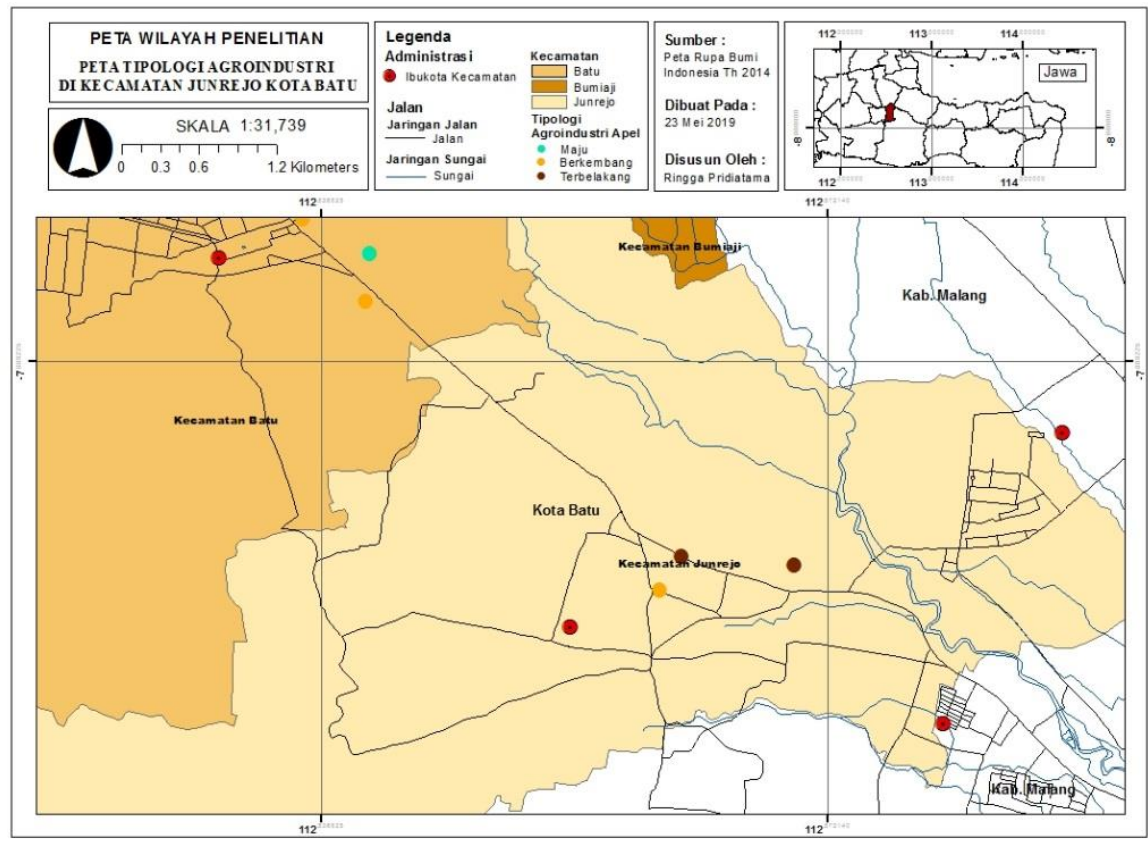

Gambar 3. Peta Tipologi Agroindustri Apel di Kecamatan Junrejo

\section{Kesimpulan}

Penelitian ini menghasilkan kesimpulan sebagai berikut. Pertama, karakteristik agroindustri apel di Kota Batu didominasi pada skala mikro, tingkat pendidikan rendah, asal bahan baku berasal dari kombinasi Kota Batu dan wilayah lain, serta lingkup pemasaran yang masih berskala lokal dan nasional. Dari hasil uji chi square diketahui bahwa Nilai Asymp. Sig sebesar 0.596 atau lebih besar daripada nilai signifikansinya $5 \%$. Dari nilai tersebut dapat disimpulkan bahwa: (1) HO diterima, yang artinya tidak ada perbedaan yang signifikan antara tingkat pendidikan dengan karakteristik skala industri apel di Kota Batu Jawa Timur, (2) Nilai Asymp. Sig sebesar 0.006. Dari nilai tersebut dapat disimpulkan bahwa $\mathrm{HO}$ ditolak, yang artinya ada perbedaan yang signifikan antara asal bahan baku dengan karakteristik skala industri apel di Kota Batu Jawa Timur, dan (3) Nilai Asymp. Sig sebesar 0.668. Dari nilai tersebut dapat disimpulkan bahwa $\mathrm{HO}$ diterima, yang artinya tidak ada perbedaan yang signifikan antara lingkup pemasaran dengan karakteristik skala industri apel di Kota Batu Jawa Timur. Secara 
keseluruhan tipologi agroindustri apel di Kota Batu terdiri atas 47 industri dengan 16 industri (34,04\%), serta kategori terbelakang 23 industri $(48,93 \%)$.

Adapun rincian tipologi berdasarkan klaster wilayah (kecamatan) adalah sebagai beikut. Pertama, jumlah keseluruhan agroindustri apel di Kecamatan Batu yakni 15, dengan rincian tipologi terdiri dari $4(26,66 \%)$ industri dengan kategori maju, 4 industri $(26,66 \%)$ kategori berkembang, dan 7 industri $(46,66 \%)$ kategori terbelakang. Kedua, jumlah keseluruhan agroindustri apel di Kecamatan Bumijai yakni 29, dengan rincian tipologi terdiri dari 4 (13,79\%) industri dengan kategori maju, 11 industri (37,93\%) kategori berkembang, dan 14 industri $(48,27 \%)$ kategori terbelakang. Ketiga, jumlah keseluruhan agroindustri apel di Kecamatan Batu yakni 3, dengan rincian tipologi terdiri dari 1 industri $(33,33 \%)$ kategori berkembang, dan 2 industri $(66,66 \%)$ kategori terbelakang .

Berdasarkan kesimpulan dari hasil penelitian, maka temuan pada penelitian ini dapat memberikan gambaran mengenai kondisi karakteristik tentang agroindustri apel di Kota Batu. Hasil tersebut dapat digunakan sebagai bahan pertimbangan maupun masukan untuk pemerintah setempat dalam melakukan perencanaan, pendekatan, hingga pengembangan arahan kedepan bagi keberlanjutan agroindustri.

Melihat kondisi yang demikian, peran pemerintah dengan porsi yang dominan dirasa dapat membantu mengatasi permasalahan maupun tantangan yang dihadapi pelaku industri, khususnya pada skala mikro. Karena semakin kecil skala industri maka peran pemerintah juga semakin besar, seperti yang diutarakan Soekartawi (2000). Mayoritas agroindustri apel di Kota Batu berskala mikro sehingga masih perlu dorongan yang lebih besar dari pemerintah setempat. kategori maju sebanyak 8 industri $(17,02 \%)$, kategori berkembang sebanyak Kemudian terkait temuan dari hasi tipologi agroindustri, dapat lebih dikaji kembali mengenai keberlanjutan bahan baku apel produksi Kota Batu yang kondisinya masih fluktuatif, pengembangan kualitas produk juga diperlukan agar dapat bertahan dan bersaing dengan produk sejenis dari daerah lain serta menambah jangkauan pasar terutama pada skala internasional.

\section{Daftar Pustaka}

Badan Pusat Statistik Jawa Timur. 2014. Analisis Sosial Ekonomi Petani di Jawa Timur (35553.1402). Surabaya: BPS Provinsi Jawa Timur. Diakses dari https://jatim.bps.go.id/publicatio n/2014/12/01/5cb0a25ba8cb9fa 914343465/analisis-sosialekonomi-petani-di-jawa-timur-analisis-hasil-surveipendapatan-petani-sensuspertanian-2013-.html

Badan Pusat Statistik Kota Batu. 2018. Kota Batu Dalam Angka (35790.1704). Batu: BPS Kota Batu. Diakses dari https://batukota.bps.go.id/public ation/2018/08/16/0359f1ad0252 52a858315ad1/kota-batudalam-angka-2018.html.

Distanont, A., Khongmalai, O. 2018. The Role of Innovation in Creating A Competitive Advantage. Kasetsart Journal of Social Sciences (https://doi.org/10.1016/j.kjss.20 18.07.009).

Departemen Perindustrian. 2010. Manajemen Industri Kecil dan Menengah. Materi Diklat Teknis Sistem Industri Aparatur. (http://www.kemenperin.go.id/elearning).

Departemen Perindustrian. 2009. Peta Panduan Pengembangan Klaster Industri Prioritas Industri Alat Angkut. (http://rocana.kemenperin.go.id/i 
ndex.php/download/category/1p?download $=3 \% 3 A p-p$ )

Hanafie, R. Suwarta. Alfiana. 2016. Variety and Characteristic of Processed Food Industry Based on Cassava. Agriculture and Agricultural Science Procedia 9:258-263.

Harrington, J.W., Warf, B. 1995. Industrial Location: Principles, Practice, and Policy. New York: Routledge.

Irawan, B., Ariningsih, E. 2014. Memperkuat Daya Saing Produk Pertanian. Jakarta: IAARD Press.

Muta'ali. L. 2015. Teknik Analisis Regional Untuk Perencanaan Wilayah, Tata Ruang, dan Lingkungan. Yogyakarta: BPFG UGM.

Pratiwi, N. A. Harianto. Daryanto, A. 2017. Peran Agroindustri Hulu dan Hilir dalam Perekonomian dan Distribusi Pendapatan Indonesia. Jurnal Manajemen \& Agribisnis, Vol. 14 (2):127-137.

Prasetyo, R.H. Santoso, E.B. 2014. Tipologi Klaster Industri Pengolahan Jagung di Kecamatan Merakurak Kabupaten Tuban Berdasarkan Karakteristik Pengembangan Ekonomi Lokalnya. Jurnal Teknik Pomits, Vol. 2 No. 1.

Purba, H.H., Maarif, M.S., Yuliasih, I., Hermawan, A. 2018. Innovation Typology in Food Industry Sector: A Literature Review. International Journal of Modern Research in Engineering and Technology, Vol.3 (2).

Pusat Komunikasi Pubik Kementrian Perindustrian. 2015. Rencana Induk Pembangunan Nasional 2015-2035. Jakarta: Kementrian Perindustrian RI. Diakses dari (http://www.kemenperin.go.id/rip in.pdf)

Ruminta. 2015. Dampak Perubahan Iklim pada Produksi Apel di Batu Malang. Jurnal Kultivasi, Vol.14 (2): $42-48$.

Suhariyono. 2014. Program Pengembangan Agribisnis Apel di Kota Batu. Diakses 1 Mei 2019, dari http://balitjestro.litbang.pertania n.go.id/programpengembangan-agribisnis-apeldi-kota-batu/

Suryaningrat, I.B. 2016. Raw Material Procurement on Agroindustrial Supply Chain Management: A Case Survey of Fruit Processing Industries in Indonesia. Agriculture and Agricultural Science Procedia 9: 253-257.

Soekartawi. 2000. Pengantar Agroindustri. Jakarta: PT RajaGrafindo Persada.

Soekartawi. 2007. Beberapa Hal yang Perlu Diperhatikan dalam Melakukan Analisis Sistem Agroindustri Terpadu. Jurnal Agribisnis dan Ekonomi Pertanian, Vol.1 (2): 31-47.

Tambunan, T. 2015. Jokowi \& Kedaulatan Pangan. Jakarta: Mitra Wacana Media.

Tan, L.T. 2000. Welfare-Maximizing and Profit-Maximizing Agroindustry Location: A Comparison. The Annals of regional Science 34, 69-82.

Udayana, I. G. B. (2015). Model Development Industrial Cluster Coffee Arabica in The District Bangli, Province of Bali. Advance Science Engineering Information Technology, 5(4), 294-297. 